\title{
Indicative Approach to Assessing the Potential for Capacity Growth in Branches of the Non- resource Sector of the Region
}

\author{
A.V. Moskvina", G.Ia. Belyakova, M.A. Likhachev, and S.V. Mikhailova \\ Siberian Federal University, Krasnoyarsk, Russia
}

\begin{abstract}
The paper considers the problem of capacity growth of the economic system in the region due to accumulated or gross value added. The gross value added, as an indicator of the economic development of territories, is represented by the following sources of development: the salary fund for supporting labour potential, depreciation and profit, as means of ensuring reproduction in business. Assessing the region's capacity potential is also carried out from the perspective of the potential of available resources accumulated by gross value added, with their subsequent transformation into the stock and labour capacity. Along with that, gross value added appears in two aspects: as a potential for resource development and as an economic effect of the subjects' activities in the region, it allows using an indicative approach to modelling situations and making management decisions for its growth at various levels - from business to industry within macro-districts and municipalities. There is a logical chain of indicators, that moves from the investment potential formed and used to support resources to the results of using it in the form of GVA and capacity. The Krasnoyarsk Krai, consisting of 6 macrodistricts and 58 territories, is an object of the research. The subject of the research was the development of production systems in the territories with access to metrics assessing the transformation quality and efficiency. Their indicative form allows classifying territories and macro-districts by their use of available resources. In general, the research is analytical and is aimed at developing the regional policy to improve the technological structure of the economy, giving it greater stability in changing markets.
\end{abstract}

\section{Introduction}

The competitive ability of the region's economy and its territories depends on the state and use of its resource potential. In this regard, one of the significant factors of its growth is considered to be the capital-labour ratio and labour capacity, which create a new consumer value of products and services due to design and engineering improvement of production and research solutions implemented.

Currently, the value added is most often associated with chains of its creation both on local and global markets, which allow improving its composition and working on the

\footnotetext{
*Corresponding author: moskanna@mail.ru
} 
effectiveness of partner networks. However today, behind this concept there is a goal of increasing labour capacity, high indicators of which can be obtained if high added value is achieved [1]. The theoretical foundations of the value added (newly created) were formulated by the classics of Economics A. Smith, D. Ricardo, J.B. Say, J.B. Clark in their works [2,3]. The value added in the concept of the surplus value is created by employees and divided among them and the capital owners.

The development of theories has led to the emergence of various concepts of added value based on income maximization. Their applied aspects are focused on the development of new mechanisms for financial management and assessment of business competitive ability. With that, there remains the problem of determining the place and role of labour capacity in the system, not only of a specific production operation, but also of industry, their home territories, significant factors and indicators for analyzing its dynamics for subsequent forecasting and management $[4,9]$.

There is a confusion of the concepts of labour capacity, enterprise production system capacity that is part of a certain economic activity, a region or territory's economic system capacity [5]. That makes it difficult to find management solutions for the priority directions of economic development. At each stage of added value formation, an analysis of its state and accumulation sources shall be made. Problem statement: the research aims to characterize the potential for value added growth in the macro-districts of the Krasnoyarsk Krai due to intensified investing for the design and engineering renewal of production facilities, the growth of their capital-labour ratio and labour capacity.

\section{Research Methodology}

The object of the research was 6 macro-districts of the Krasnoyarsk Krai (Southern, Northern, Angara, Eastern, Western, Central) and 58 municipalities.

The subject of the research is focused on forming the GVA and capacity through an indicative system of metrics involved in investing a resource potential and evaluating the effectiveness of its use.

The research information base was made up of statistical materials of the Krasnoyarskstat (Federal Statistics Office of Krasnoyarsk Krai, the Republic of Khakassia and the Tyva Republic) and the Automated Information System for Monitoring Municipalities of the Ministry of Economy and Regional Development of the Krasnoyarsk Krai.

Research period: 2016-2019.

The stages of the research are the following:

1. Characteristics of the gross value added by territories of the region;

2. Analysis of the structural elements of gross value added by territories of the region;

3. Analysis of fixed assets and investment intensity for their renewal;

4. Characteristics of the capital-labour ratio and labour capacity by macro-districts of the region;

5. Comparative analysis of investment impact on updating the design and engineering state of production systems;

6. Formation of metrics for design and engineering renewal effectiveness of the economy of territories. Assessment of the impact of capital-labour ratio and labour capacity on gross value added.

As metrics (indicators) of the state and effectiveness of the economic system of macrodistricts, the following are defined: investments in fixed assets (Ifa) to the cost of fixed assets (FA) - Ifa/FA, investments in fixed assets to the financial result (FR) - Ifa/FR, investments in fixed assets to gross value added (GVA) - Ifa/GVA, capital-labour ratio (CLR) to investments in fixed assets - CLR/Ifa, labour capacity (LC) to investments in 
fixed assets - Ifa/LC, labour capacity to capital-labour ratio - LC/CLR and gross value added to labour capacity and capital-labour ratio - GVA/LC/CLR [6-7].

\section{Findings}

The dynamics of GVA by macro-districts of the region is presented in Table 1. The highest values of GVA are in the Northern and Central macro-districts of the Krasnoyarsk Krai. Along with that, the trends are different: from negative gains and sharp fluctuations in the Northern macro-district to smoother declines/growth in the Central one. In general, during the period under review, the growth of GVA took place in the Southern (107.4\%) and Eastern (108.8\%) macro-districts.

Table 1. Trends in GVA in macro-districts of the Krasnoyarsk Krai in 2016-2019.

\begin{tabular}{|c|c|c|c|c|c|c|c|c|}
\hline \multirow{2}{*}{$\begin{array}{l}\text { Macro- } \\
\text { districts }\end{array}$} & \multicolumn{4}{|c|}{ Indicator values, thousand rubles. } & \multicolumn{3}{|c|}{ Growth ratio } & \multirow[b]{2}{*}{$\begin{array}{c}\text { Avera } \\
\text { ge } \\
\text { annua } \\
\text { l } \\
\text { growt } \\
\text { h } \\
\text { rate, } \\
\%\end{array}$} \\
\hline & 2016 & 2017 & 2018 & 2019 & 2017 & 2018 & 2019 & \\
\hline $\begin{array}{c}\text { Souther } \\
\mathrm{n}\end{array}$ & $\begin{array}{c}14,50 \\
6,882 . \\
6\end{array}$ & $\begin{array}{c}1,253,64 \\
2,527.6\end{array}$ & $\begin{array}{c}15,931,7 \\
87.7\end{array}$ & $\begin{array}{c}18,095,5 \\
33.8\end{array}$ & 106.7 & 106.7 & 111.3 & 107.4 \\
\hline $\begin{array}{c}\text { Norther } \\
n\end{array}$ & $\begin{array}{c}550,9 \\
82,26 \\
6.5\end{array}$ & $\begin{array}{c}388,569 \\
675.4\end{array}$ & $\begin{array}{c}408,100, \\
116.3\end{array}$ & $\begin{array}{c}500,454, \\
891.6\end{array}$ & -26.0 & 140.2 & 260.1 & 17.6 \\
\hline Angara & $\begin{array}{c}80,66 \\
0,951 . \\
2\end{array}$ & $\begin{array}{c}272,366, \\
899.5\end{array}$ & $\begin{array}{c}173,424 \\
459.5\end{array}$ & $\begin{array}{c}96,228,2 \\
16.1\end{array}$ & 115.9 & 88.9 & 57.7 & 90.4 \\
\hline Eastern & $\begin{array}{c}26,99 \\
7,563 . \\
0\end{array}$ & $\begin{array}{c}26,618,8 \\
62.5\end{array}$ & $\begin{array}{c}28,221,3 \\
43.2\end{array}$ & $\begin{array}{c}29,828,5 \\
97.6\end{array}$ & 99.6 & 108.8 & 103.2 & 100.8 \\
\hline Western & $\begin{array}{c}60,41 \\
7,869 . \\
2\end{array}$ & $\begin{array}{c}52,588,6 \\
35.0\end{array}$ & $\begin{array}{c}49,611,2 \\
48.9\end{array}$ & $\begin{array}{c}52,509,3 \\
26.4\end{array}$ & 98.30 & 98.5 & 97.4 & 95.9 \\
\hline Central & $\begin{array}{c}225,3 \\
02,84 \\
7.5\end{array}$ & $\begin{array}{c}343,378 \\
062.2\end{array}$ & $\begin{array}{c}331,448, \\
029.5\end{array}$ & $\begin{array}{c}444,135 \\
442.3\end{array}$ & 144.4 & 96.5 & 118.7 & 94.0 \\
\hline
\end{tabular}

The main elements of the GVA are the salary fund, depreciation deductions and profit [8]. Such a structure of the GVA allows considering it as an investment resource, aimed at supporting the vital activity and development of human potential, compensating for the physical depreciation of fixed assets and business development. The more a territory accumulates profits, the more opportunities it has to spend on investment programs to support the design and engineering level and production system capacity.

The more the salary fund accumulates in the territory, the more opportunities there are to support the development of human potential and the growth of its quality under production renewal.

According to the results of 2019, the Northern macro-district had the highest profit share in the structure of GVA - 65.4\%- (Table 2). The Central macro-district was distinguished by the balanced structure of the GVA: the salary fund and profit had approximately the same share (40\%). 
Table 2. The GVA structure of the macro-districts of the Krasnoyarsk Krai, \%

\begin{tabular}{|c|c|c|c|c|}
\hline Macro-districts & Salary fund & $\begin{array}{c}\text { Depreciation } \\
\text { deductions }\end{array}$ & Profit & GVA \\
\hline \hline Southern & 87.8 & 9.5 & 2.6 & 100.0 \\
\hline Northern & 26.6 & 17.1 & 65.4 & 100.0 \\
\hline Angara & 41.1 & 16.6 & 2.2 & 100.0 \\
\hline Eastern & 85.4 & 6.6 & 7.3 & 100.0 \\
\hline Western & 72.4 & 13.1 & 14.5 & 100.0 \\
\hline Central & 42.4 & 18.1 & 39.5 & 100.0 \\
\hline
\end{tabular}

The analysis result allowed to identify clusters of micro-district territories with different typologies of the structure and establish their relationship with the GVA.

The structure of the gross value added of the territories in 2016-2019 is shown in Figure 1. From the perspective of the GVA, each territory is classified according to its composition for each period of time.

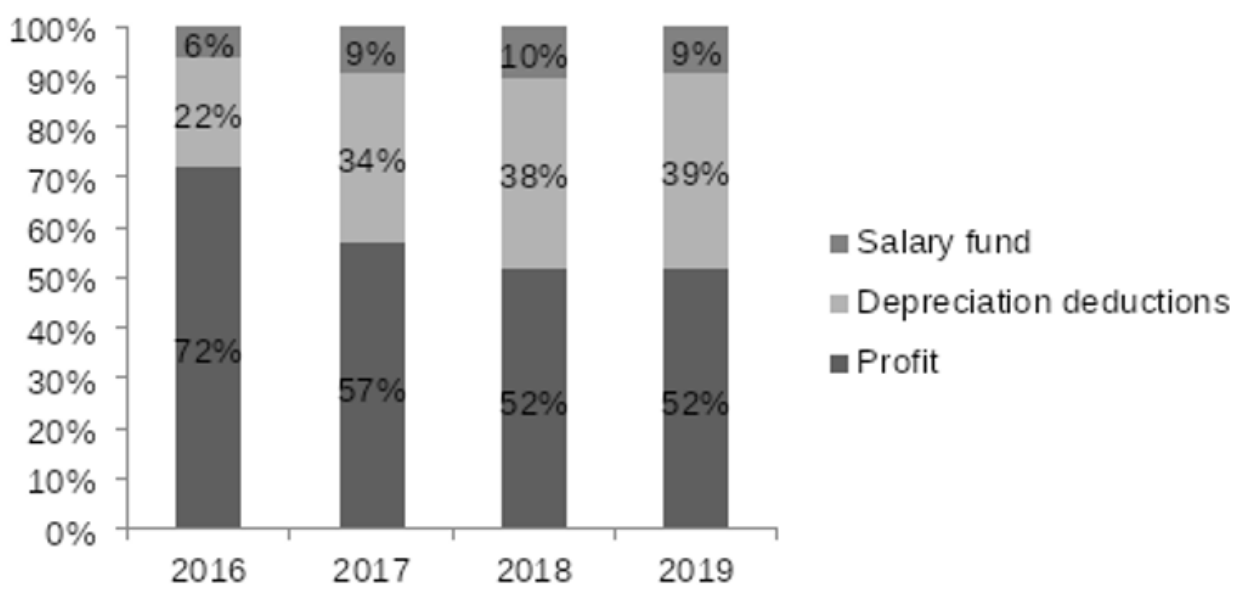

Fig. 1. The GVA structure of the territories of the Krasnoyarsk Krai by elements in 2016-2019, \%

From the perspective of the GVA, each territory is classified according to its composition for each period of time. The average values of depreciation deduction shares, the salary fund, and profit within the clusters of territories for 2019 are shown in Table 3, Figure 2.

Table 3. The average values of the GVA structural elements used in the differentiation of territories in $2019, \%$

\begin{tabular}{|c|c|c|c|c|c|c|c|}
\hline $\begin{array}{c}\text { Relative } \\
\text { share }\end{array}$ & Cluster 1 & Cluster 2 & Cluster 3 & Cluster 4 & Cluster 5 & Cluster 6 & Cluster 7 \\
\hline \hline $\begin{array}{c}\text { Labour } \\
\text { remuneration }\end{array}$ & 96.30 & 22.40 & 3.63 & 14.48 & 54.40 & 27.36 & 71.82 \\
\hline Depreciation & 158.01 & 42.33 & 14.50 & 30.48 & 35.21 & 63.39 & 10.69 \\
\hline Profit & -154.31 & 35.27 & 81.87 & 55.04 & 10.39 & 9.25 & 17.49 \\
\hline
\end{tabular}




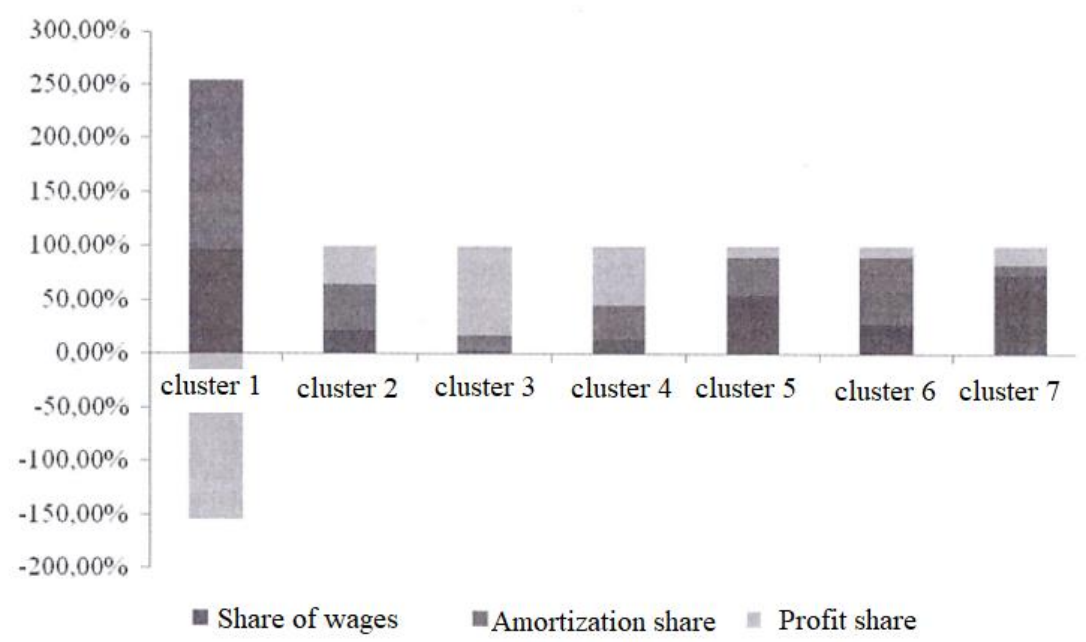

Fig. 2. The GVA structure in the municipalities of the Krasnoyarsk Krai in 2019.

Clustering was based on identifying maximum differences between the observations for each period.

The classification of territories by selected clusters is shown in Table 4.

Table 4. Classification of municipalities of the region by the GVA composition in 2019

\begin{tabular}{|c|c|c|c|c|c|c|}
\hline $\begin{array}{c}\text { Cluster 1 } \\
1 \\
\text { municipali } \\
\text { ty }\end{array}$ & $\begin{array}{c}\text { Cluster } 2 \\
9 \\
\text { municipali } \\
\text { ties }\end{array}$ & $\begin{array}{c}\text { Cluster } 3 \\
7 \\
\text { municipali } \\
\text { ties }\end{array}$ & $\begin{array}{c}\text { Cluster } 4 \\
4 \\
\text { municipali } \\
\text { ties }\end{array}$ & $\begin{array}{c}\text { Cluster } 5 \\
8 \\
\text { municipali } \\
\text { ties }\end{array}$ & $\begin{array}{c}\text { Cluster } 6 \\
13 \\
\text { municipaliti } \\
\text { es } \\
\end{array}$ & $\begin{array}{c}\text { Cluster } 7 \\
16\end{array}$ \\
\hline $\begin{array}{c}\text { Evenkiysk } \\
\mathrm{y}\end{array}$ & $\begin{array}{c}\text { Achinsk } \\
\text { Nazarovo } \\
\text { Yemelyan } \\
\text { ovsky } \\
\text { Yeniseysk } \\
\text { y } \\
\text { Kansky } \\
\text { Krasnotur } \\
\text { ansky } \\
\text { Novosyol } \\
\text { ovsky } \\
\text { Rybinsky } \\
\text { Uzhursky }\end{array}$ & $\begin{array}{c}\text { Divnogor } \\
\text { ks } \\
\text { Norilsk } \\
\text { Motygins } \\
\text { ky } \\
\text { Severo- } \\
\text { Yeniseysk } \\
\text { y }\end{array}$ & $\begin{array}{c}\text { Abansky } \\
\text { Bolsheulu } \\
\text { ysky } \\
\text { Nazarovsk } \\
\text { y } \\
\text { Sukhobuzi } \\
\text { msky } \\
\text { Turukhans } \\
\text { ky } \\
\text { Uyarsky } \\
\text { Sharypovs } \\
\text { ky }\end{array}$ & $\begin{array}{c}\text { Birilyussk } \\
\text { y } \\
\text { Bolshemu } \\
\text { rtinsky } \\
\text { Dzerzhins } \\
\text { ky } \\
\text { Yermakov } \\
\text { sky } \\
\text { Idrinsky } \\
\text { Kazachins } \\
\text { ky } \\
\text { Minusinsk } \\
\text { y } \\
\text { Partizansk } \\
\text { y }\end{array}$ & $\begin{array}{c}\text { Kedrovy } \\
\text { Krasnoyarsk } \\
\text { Sosnovobor } \\
\text { sk } \\
\text { Beryozovsk } \\
\text { y } \\
\text { Bogotolsky } \\
\text { Boguchansk } \\
\text { y } \\
\text { Irbeysky } \\
\text { Kezhemsky } \\
\text { Kozulsky } \\
\text { Kuraginsky } \\
\text { Nizhneingas } \\
\text { hsky } \\
\text { Taymyrsky } \\
\text { Shushensky }\end{array}$ & $\begin{array}{l}\text { Bogotol } \\
\text { Borodino } \\
\text { Yeniseysk } \\
\text { Kansk } \\
\text { Lesosibirsk } \\
\text { Minusinsk } \\
\text { Sharypovo } \\
\text { Achinsky } \\
\text { Balakhtinsk } \\
\text { y } \\
\text { Ilansky } \\
\text { Karatuzsky } \\
\text { Mansky } \\
\text { Pirovsky } \\
\text { Sayansky } \\
\text { Taseyevsky } \\
\text { Tyukhtetsky }\end{array}$ \\
\hline
\end{tabular}

The cluster analysis of the GVA structure by the territories of the region allowed drawing the following conclusions:

- the structure is mobile, which is due to new clusters appearing (cluster 7 in 2019), as well as changes in the boundaries of cluster 4;

- the selection of typical clusters indicates the presence of patterns in the GVA formation. Clusters 1, 2, 3, 5, 6 became common (repeating in structure).

The classification of territories by clusters and GVA growth rates is shown in Figure 3. 


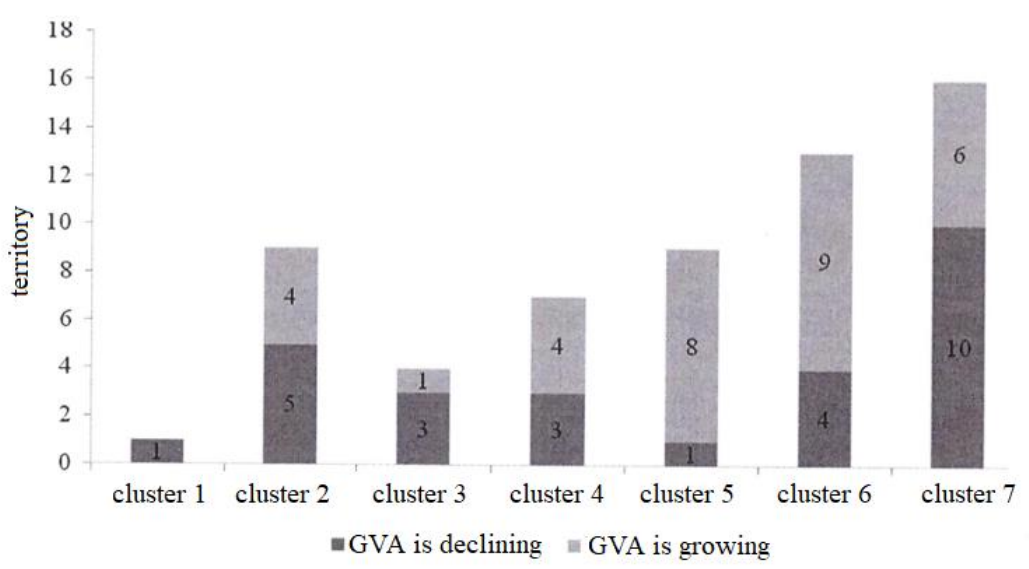

Fig. 3. Territories of macro-districts of the Krasnoyarsk Krai in 2019, depending on the growth rate of GVA, units.

The relationship between the GVA formation structure and the indicator growth rate by territory revealed the following clustering possibilities (tables 5-6).

Table 5. Classification of municipalities that showed a decrease in GVA for 2016-2019.

\begin{tabular}{|c|c|c|c|c|c|c|}
\hline $\begin{array}{c}\text { Cluster } \\
1 \\
1 \\
\text { municip } \\
\text { ality } \\
\end{array}$ & $\begin{array}{c}\text { Cluster } 2 \\
5 \\
\text { municipalitie } \\
\text { s }\end{array}$ & $\begin{array}{c}\text { Cluster } 3 \\
3 \\
\text { municipaliti } \\
\text { es }\end{array}$ & $\begin{array}{c}\text { Cluster } 4 \\
3 \\
\text { municipaliti } \\
\text { es }\end{array}$ & $\begin{array}{c}\text { Cluster } 5 \\
1 \\
\text { municipali } \\
\text { ty }\end{array}$ & $\begin{array}{c}\text { Cluster } \\
6 \\
4 \\
\text { municip } \\
\text { alities } \\
\end{array}$ & $\begin{array}{c}\text { Cluster } 7 \\
10 \\
\text { municipaliti } \\
\text { es }\end{array}$ \\
\hline $\begin{array}{c}\text { Evenkiy } \\
\text { sky }\end{array}$ & $\begin{array}{c}\text { Achinsk } \\
\text { Kansky } \\
\text { Krasnoturan } \\
\text { sky } \\
\text { Novosyolovs } \\
\text { ky } \\
\text { Uzhursky }\end{array}$ & $\begin{array}{l}\text { Divnogorks } \\
\text { Norilsk } \\
\text { Severo- } \\
\text { Yeniseysky }\end{array}$ & $\begin{array}{c}\text { Bolshe- } \\
\text { uluysky } \\
\text { Nazarovsky } \\
\text { Turukhansk } \\
\text { y }\end{array}$ & Idrinsky & $\begin{array}{c}\text { Kedrovy } \\
\text { Krasnoy } \\
\text { arsk } \\
\text { Irbeysky } \\
\text { Shushen } \\
\text { sky }\end{array}$ & $\begin{array}{c}\text { Bogotol } \\
\text { Borodino } \\
\text { Kansk } \\
\text { Balakhtinsk } \\
\text { y } \\
\text { Ilansky } \\
\text { Karatuzsky } \\
\text { Mansky } \\
\text { Sayansky } \\
\text { Taseyevsky } \\
\text { Tyukhtetsky }\end{array}$ \\
\hline
\end{tabular}

Table 6. Classification of the territories of the Krasnoyarsk Krai that showed a more than double increase in GVA in 2016-2019.

\begin{tabular}{|c|c|c|c|c|c|c|}
\hline $\begin{array}{l}\text { Clust } \\
\text { er } 1\end{array}$ & $\begin{array}{c}\text { Cluster } 2 \\
1 \\
\text { municipali } \\
\text { ty }\end{array}$ & $\begin{array}{c}\text { Cluster } \\
3 \\
1 \\
\text { municip } \\
\text { ality } \\
\end{array}$ & $\begin{array}{c}\text { Cluster } 4 \\
3 \\
\text { municipaliti } \\
\text { es }\end{array}$ & $\begin{array}{c}\text { Cluster } 5 \\
7 \\
\text { municipalities }\end{array}$ & $\begin{array}{c}\text { Cluster } 6 \\
3 \\
\text { municipalities }\end{array}$ & $\begin{array}{c}\text { Cluster } 7 \\
6 \\
\text { municipaliti } \\
\text { es }\end{array}$ \\
\hline & Rybinsky & $\begin{array}{l}\text { Motygin } \\
\text { sky }\end{array}$ & $\begin{array}{c}\text { Abansky } \\
\text { Sukhobuzi } \\
\text { msky } \\
\text { Uyarsky }\end{array}$ & $\begin{array}{c}\text { Birilyussky } \\
\text { Bolshemurtins } \\
\text { ky } \\
\text { Dzerzhinsky } \\
\text { Yermakovsky } \\
\text { Kazachinsky } \\
\text { Minusinsky } \\
\text { Partizansky }\end{array}$ & $\begin{array}{c}\text { Beryozovsky } \\
\text { Boguchansky } \\
\text { Kuraginsky }\end{array}$ & $\begin{array}{c}\text { Yeniseysk } \\
\text { Lesosibirsk } \\
\text { Minusinsk } \\
\text { Sharypovo } \\
\text { Achinsky } \\
\text { Pirovsky }\end{array}$ \\
\hline
\end{tabular}


GVA growth territories in groups with the structure of:

- partially cluster 2 (profit and depreciation in the amount of more than 77\%),

- partially cluster 4 (profit and depreciation in the amount of more than $85 \%$ ),

- cluster 5 (labour remuneration - high, depreciation - average, profit - low),

- cluster 6 (depreciation prevails, profit is insignificant),

- cluster 7 (labour remuneration significantly prevails to the detriment of other elements).

The reduction of GVA occurs in territories with the structure:

- cluster 1 (loss),

- partially cluster 2 (profit and depreciation in the amount of more than 77\%),

- cluster 3 (high profit share to the detriment of other elements),

- partially cluster 4 (profit and depreciation in the amount of more than $85 \%$ ),

- cluster 6 (depreciation prevails, profit is insignificant),

- cluster 7 (labour remuneration significantly prevails).

Territories, where there is a loss in the GVA structure, do not show positive growth in GVA (cluster 1), as well as territories where profit prevails in the structure to the detriment of other elements (cluster 3 ). Territories, where an average amortization share is added to a high profit with a low share of wages, are characterized by both a decrease and an increase in GVA (cluster 4). The reallocation of GVA in favour of a larger share of wages with a high total profit and amortization (cluster 2) does not allow characterizing unambiguously the dynamics of GVA.

Mainly, the growth of GVA is shown by territories where the profit share is low (up to $10 \%$ ), and the total amount of labour remuneration and depreciation is up to $90 \%$ (clusters 5 and 6). However, the low profit share itself does not characterize the territory as growing: for example, in cluster 7 , the share of wages is more than $70 \%$ (the profit is small), but the amortization share is low. This cluster includes both growing territories and territories with a decreasing GVA value.

Thus, the high profit share does not indicate the potential for GVA growth. Growth is more likely when profits are redistributed in favour of both depreciation and labour remuneration. However, the clear predominance of labour remuneration also makes GVA growth prospects ambiguous.

The analysis confirms the need to achieve a balanced structure of the GVA. An "imbalance" towards only profit, profit and depreciation, or labour remuneration solely does not guarantee growth. Besides, the GVA growth is impossible with a low share of wages, the human factor is no less important than the process or the entrepreneurship one. Only a balanced combination of labour remuneration, depreciation (mostly) and profit (less) create opportunities for further development.

The study of the GVA, the structure of which contains profit and depreciation, allows evaluating it as an own investment resource for the development of territories. The analysis of investment statistics shows that they were accompanied by the introduction/disposal of fixed assets, and in some cases led to negative average annual growth/gain rates. The most active processes were developed in the manufacturing industries, in part, transport and construction. For example, in the Central macro-district - the centre of the manufacturing industry of the region, in Krasnoyarsk, in particular, the excess of input over the disposal of fixed assets was 3.49 rubles, in the Balakhtinsky District - 15.65 rubles, and the Bolshemurtinsky District - 7.59 rubles. Inputting high volumes of fixed assets in the manufacturing industries were confirmed in Achinsk - 107.45 rubles. and the Uzhursky District - 476.91 rubles.

The effectiveness of investing in terms of heir reproductive functions implemented was assessed based on the metric investment indicator in fixed assets, accounting for 1 ruble of fixed assets value (Table 7) 
Table 7. Comparative assessment of the degree of fixed assets depreciation and $\mathrm{I}_{\mathrm{fa}}$ allocated for its compensation in the macro-districts of the Krasnoyarsk Krai in 2019.

\begin{tabular}{|c|c|c|c|}
\hline Macro-districts & Degree of fixed assets & \multicolumn{2}{|c|}{ Ifa/FA } \\
\cline { 3 - 4 } & & Value & $\begin{array}{c}\text { Average annual } \\
\text { depreciation }\end{array}$ \\
\hline \hline Central & 45.2 & 0.16 & 100.4 \\
\hline Western & 51.2 & 0.10 & 104.2 \\
\hline Eastern & 63.2 & 0.10 & 91.8 \\
\hline Northern & 37.01 & 0.33 & 85.6 \\
\hline Angara & 43.6 & 0.19 & 80.4 \\
\hline Southern & 61.8 & 0.07 & 81.6 \\
\hline
\end{tabular}

More than half of the fixed assets are beyond the service life in the Southern macrodistrict. Production facilities in Minusinsk are completely worn out, in the Idrinsky District - worn out by $74.4 \%$, in the Karatuzsky District - by 59.7\%, in the Shushensky District - by $58.4 \%$ and require replacement of equipment. Own resources and accumulated depreciation deductions (4 times greater than the financial result of the territory) are enough for the development of production facilities on a new process basis, but this does not happen.

In the Angara macro-district, the situation with depreciation is relatively smooth (43.6\%), in the Kezhemsky District, fixed assets are new, their depreciation is only $3.13 \%$. In the Northern macro-district, such territories include the Taymyrsky District (6.3\%).

The difficult situation with the technical condition of production facilities is in the Eastern macro-district. With an average degree of fixed assets depreciation of $63.2 \%$, high values are in the Partizansky $(92.8 \%)$ and Sayansky $(82.3 \%)$ districts. The situation is similar in Achinsk (100\%) and Birilyussky District (81.5\%). Slight depreciation in AchinskH (12.0\%) and Nazarovsky districts (28.2\%).

In the Central macro-district, despite the average level of depreciation (45.2\%), the technical condition of the production potential in the territories is different: three-quarters of the equipment is worn out in Krasnoyarsk, a third - in Sosnovoborsk (27.0\%), Mansky $(35 \%)$ and Sukhobuzimsky (38\%) districts, half - in Beryozovsky (44.3\%) and Yemelyanovsky (47.8\%) districts.

The investment resources of the territories are sufficient to compensate from 7 to $33 \%$ of the cost of fixed assets. There is a great potential for expanding production facilities in the Northern (0.33 rub/rub), Angara (0.19 rub/rub) and Central (0.16 rub/rub) macrodistricts. Such opportunities are limited in the Western, Eastern and Southern macrodistricts. The rate of these processes development has a positive dynamics only in the Western and Central macro-districts, in the rest it is unstable in 2016-2019.

In general, investment resources do not allow predicting the reproduction quality in the Southern, Eastern and Western macro-districts of the region.

The analysis of the territories' own investment potential, which is based on the final financial result of economic entities, indicates that:

1. a large number of them have negative results of activity that doesn't include own investments in the development of production facilities;

2. more than a quarter of the subjects in the region invest their own funds with different dynamics of their gain during the period under review.

So, in 2019, such territories as Sayansky, Achinsky, Kozulsky, Yeniseysky, Evenkiysky, Yermakovsky, Kuraginsky districts and such cities as Bogotol, Sharypovo, Lesosibirsk, Norilsk did not have their own investment potential. Along with that, some territories had positive dynamics of the average annual growth rates. Kozulsky District 178.2\%, Yeniseysky District - 106.2\%, Evenkiysky District - 526.9\%, Yermakovsky District $-254.8 \%$, Kuraginsky District $-107 \%$. The growth rates of own investment 
resources decreased in Achinsk (-20.0), Nazarovo (-40.5), Kezhemsky (-20.3), Motyginsky (-13.2), Kirovsky (-43.2), Turukhansky (-5.1) districts, Divnogorsk (-15.5), Krasnoyarsk (47.0), Bolshemurtinsky (-63.5), Idrinsky (-20.3), Shushensky (-165.9) districts.

GVA, creating the potential for investment opportunities for updating fixed assets and expanding production facilities, increases the capital-labour ratio and labour capacity [10]. The comparative characteristics of these indicators for the territories of the region allow giving a generalized characteristic of the efficiency of the sources used (Table 8)

Table 8. Comparative characteristics of the growth rates of FA, GVA and LC indicators in the Southern macro-district of the Krasnoyarsk Krai, \%

\begin{tabular}{|c|c|c|c|}
\hline MO & GVA & CLR & LC \\
\hline \hline Minusinsk & 104.5 & 99.7 & 99.5 \\
\hline Yermakovsky & 106.8 & 120.2 & 111.1 \\
\hline Idrinsky & 107.9 & 105.3 & 101.1 \\
\hline Karatuzsky & 103.9 & 116.6 & 107.7 \\
\hline Krasnoturansky & 105.6 & 114.6 & 106.8 \\
\hline Kuraginsky & 112.7 & 116.0 & 117.1 \\
\hline Minusinsky & 101.2 & 107.5 & 99.0 \\
\hline Shushensky & 116.6 & 139.3 & 118.0 \\
\hline On average & 107.4 & 114.9 & 107.5 \\
\hline
\end{tabular}

Thus, in the Southern macro-district, the growth of the capital-labour ratio contributed to the growth of labour capacity in most territories: Yermakovsky, Krasnoturansky, Idrinsky, Kuraginsky, Karatuzsky, Shushensky districts. In the Minusinsky District, the capital-labour ratio $(+75 \%)$ did not provide an adequate increase in labour capacity $(-1.0 \%)$. In Minusinsk (-0.3\%), its decline was also reflected in labour capacity $(-0.5 \%)$.

In the Central macro-district, the situation is similar - in most territories, in response to the increase in the level of design and engineering support, labour capacity has increased. Deferred investment results are predicted in Sosnovoborsk and Balakhtinsky districts (Table 9)

Table 9. Comparative characteristics of the growth rates of CLR, GVA and LC indicators in the Central micro-district in the Krasnoyarsk Krai, \%

\begin{tabular}{|c|c|c|c|}
\hline MO & GVA & CLR & LC \\
\hline \hline Divnogorks & 110.9 & 102.8 & 110.1 \\
\hline Krasnoyarsk & 125.8 & 117.7 & 127.4 \\
\hline Sosnovoborsk & -62.4 & 130.1 & -63.0 \\
\hline Balakhtinsky & 99.1 & 108.7 & 95.4 \\
\hline Beryozovsky & 110.2 & 116.4 & 112.8 \\
\hline Bolshemurtinsky & 136.3 & 133.5 & 137.6 \\
\hline Yemelyanovsky & 101.9 & 106.0 & 104.4 \\
\hline Mansky & 107.9 & 106.7 & 105.6 \\
\hline Sukhobuzimsky & 97.5 & 112.5 & 107.7 \\
\hline On average & 91.9 & 114.9 & 92.4 \\
\hline
\end{tabular}

In other macro-districts of the region, the situation is ambiguous by territory. Thus, in the Eastern macro-district with average indicators of the capital-labour ratio, only half of the territories increased labour capacity, and in the Rybinsk District it got negative values (Table 10).

Table 10. Comparative assessment of the growth rates of CLR, GVA and LC in the Eastern macrodistrict of the Krasnoyarsk Krai in 2016-2019, \% 


\begin{tabular}{|c|c|c|c|}
\hline MO & GVA & CLR & LC \\
\hline \hline Borodino & 113.1 & 104.6 & 107.8 \\
\hline Kansk & 103.2 & 112.5 & 108.0 \\
\hline Abansky & 100.0 & 113.3 & 94.8 \\
\hline Dzerzhinsky & 35.8 & 99.3 & 34.7 \\
\hline Ilansky & 105.1 & 104.4 & 105.1 \\
\hline Irbeysky & 114.3 & 111.4 & 120.4 \\
\hline Kansky & 106.6 & 110.5 & 109.8 \\
\hline Nizhneingashsky & 102.1 & 107.6 & 102.9 \\
\hline Partizansky & 127.2 & 118.7 & 130.4 \\
\hline Rybinsky & 97.3 & 111.5 & 100.2 \\
\hline Sayansky & 104.0 & 111.0 & 109.2 \\
\hline Taseyevsky & 99.2 & 102.5 & 95.9 \\
\hline Uyarsky & 102.1 & 106.0 & 98.8 \\
\hline On average & 100.7 & 108.0 & 101.4 \\
\hline
\end{tabular}

There are two such territories in the Western macro-district: the city of Achinsk and the Birilyussky District. There are more territories where the response to the capital-labour ratio was significantly lower than expected (Table 11).

Table 11. Comparative assessment of the growth rates of CLR, GVA and LC in the Western macrodistrict of the Krasnoyarsk Krai, \%

\begin{tabular}{|c|c|c|c|}
\hline MO & GVA & CLR & LC \\
\hline \hline Achinsk & 103.8 & 110.0 & 100.0 \\
\hline Bogotol & 104.6 & 104.9 & 103.3 \\
\hline Nazarovo & 107.1 & 108.4 & 112.6 \\
\hline Sharypovo & 96.9 & 105.2 & 104.2 \\
\hline Achinsky & 71.7 & 98.9 & 63.9 \\
\hline Birilyussky & 103.2 & 102.1 & 100.3 \\
\hline Bogotolsky & 83.1 & 105.6 & 78.3 \\
\hline Bolsheuluysky & 71.9 & 109.7 & 75.7 \\
\hline Kozulsky & 105.6 & 107.5 & 104.9 \\
\hline Nazarovsky & 92.4 & 104.7 & 95.5 \\
\hline Novosyolovsky & 100.0 & 111.6 & 101.0 \\
\hline Tyukhtetsky & 104.3 & 118.0 & 101.8 \\
\hline Uzhursky & 100.6 & 110.5 & 98.3 \\
\hline Sharypovsky & 97.6 & 95.6 & 97.4 \\
\hline On average & 95.9 & 106.6 & 95.5 \\
\hline
\end{tabular}

In the Angara macro-district, a negative GVA was formed in the Boguchansky District $(-6 \%)$. However, it was not possible to achieve high rates of labour capacity growth $(+0.6 \%)$ with the available capital-labour ratio (Table 12$)$.

Table 12. Comparative assessment of the growth rates of CLR, GVA and LC in the Angara macrodistrict of the Krasnoyarsk Krai, \%

\begin{tabular}{|c|c|c|c|}
\hline MO & GVA & CLR & LC \\
\hline \hline Yeniseysk & 37.6 & 113.2 & 37.2 \\
\hline Lesosibirsk & 32.5 & 107.4 & 31.5 \\
\hline Boguchansky & 94.0 & 225.3 & 100.6 \\
\hline Yeniseysky & 100.1 & 74.0 & 105.4 \\
\hline Kazachinsky & 106.2 & 109.5 & 113.5 \\
\hline Kezhemsky & 106.8 & 98.8 & 102.1 \\
\hline Motyginsky & 126.7 & 105.3 & 122.0 \\
\hline
\end{tabular}




\begin{tabular}{|c|c|c|c|}
\hline Pirovsky & 106.7 & 105.3 & 99.4 \\
\hline Severo-Yeniseysky & 102.3 & 112.1 & 99.8 \\
\hline On average & 90.3 & 116.7 & 90.2 \\
\hline
\end{tabular}

\section{Discussion}

Summarizing the analysis results and assessing the effectiveness of design and engineering improvement of territories' production systems aimed at GVA growth, we will highlight metrics (indicators) that measure its level, based on comparative estimates.

The metrics (indicators) that measure the consumption of production system resources in the design and engineering improvement include GVA and Ifa. The efficiency of using resources for consistent GVA growth is determined by a chain of metrics that assess the contribution of investments to the growth of GVA and CLR (Ifa/GVA, Ifa/CLR), their return in the form of an increase in capital-labour ratio and labour capacity (CLR/Ifa, LC/Ifa), the impact of capital-labour ratio on labour capacity (LC/CLR) and their total return in the form of GVA growth (GVA/LC/CLR).

The metrics of the production systems state in the territories are presented in Table 13.

Table 13. Characteristics of the dynamics of design and engineering renewal of the production systems in the territories of the region according to the average annual growth rates for $2016-2019, \%$

\begin{tabular}{|c|c|c|c|c|}
\hline Macro-districts & GVA & Ifa & CLR & LC \\
\hline \hline Southern (8) & 107.4 & 93.7 & 114.9 & 107.5 \\
\hline Northern (4) & 17.6 & 105.6 & 135.4 & 47.1 \\
\hline Angara (9) & 90.4 & 88.1 & 116.8 & 90.2 \\
\hline Eastern (13) & 100.8 & 94.2 & 108.7 & 101.3 \\
\hline Western (14) & 95.9 & 109.7 & 106.4 & 101.1 \\
\hline Central (10) & 94.0 & 112.0 & 112.7 & 93.7 \\
\hline
\end{tabular}

The relative characteristics of the metrics give a more visual picture of changes in the economy of the territories of the region (Table 14)

Table 14. The impact of design and engineering improvement of production systems of macrodistricts on GVA growth potential, \%

\begin{tabular}{|c|c|c|c|c|c|c|}
\hline $\begin{array}{c}\text { Macro- } \\
\text { districts }\end{array}$ & Ifa/GVA & Ifa/CLR & CLR/Ifa & LC/Ifa & LC/CLR & GVA/LC/CLR \\
\hline \hline Southern & 0.872 & 0.815 & 1.226 & 1.147 & 0.935 & 114.8 \\
\hline Northern & 6.0 times & 0.780 & 1.282 & 0.446 & 0.348 & 50.6 \\
\hline Angara & 0.974 & 0.754 & 1.326 & 1.024 & 0.772 & 117.1 \\
\hline Eastern & 0.934 & 0.867 & 1.154 & 1.075 & 0.932 & 108.1 \\
\hline Western & 1.145 & 1.032 & 0.969 & 0.921 & 0.950 & 100.9 \\
\hline Central & 1.191 & 0.994 & 1.006 & 0.836 & 0.831 & 113.1 \\
\hline
\end{tabular}

\section{Conclusion}

Characterizing the territories along the entire chain of the presented dependencies, we note the following:

1. In the Southern macro-district, the contribution of investments to GVA and CLR formation was adequate, as was the response to them. The capital-labour ratio, as well as labour capacity, increased, but not all of its potential manifested (0.935). Despite this, the GVA increased by $114.8 \%$. There is a potential for further growth; 
2. In the Northern macro-district, 6 rubles of investment funds were invested for each ruble of the GVA, at this stage they provided an increase in the capital-labour ratio (1.282). However, there was no adequate return on labour capacity at the reviewed stage $(0.348)$. The growth potential is estimated 50 times of the amount;

3. In the Angara macro-district, the return on investment is high, labour capacity is growing more slowly, but this does not prevent from assessing the efficiency of the production system of the territories as significant (117.1\%);

4. In the Eastern macro-district, the situation is similar, the production system of the territories has a GVA growth potential of $-108.1 \%$;

5. The Western macro-district responded to the investments $(1.145 \mathrm{rub} / \mathrm{rub})$ with a decrease in the capital-labour ratio and labour capacity. Moreover, the increase in the first indicator over the second provided a small increase in the GVA $(0.9 \%)$. In general, the effectiveness of design and engineering development is estimated as low;

6. In the Central macro-district, as in the Southern one, there is a high return on invested capital. The excess of the capital-labour ratio over labour capacity allowed reaching the GVA growth at the level of $13.1 \%$. However, the findings allow to assume higher growth rates in the subsequent period.

In general, the conducted research made it possible to obtain an analytical database of the region for solving and adjusting management tasks to increase added value and capacity.

The use of metrics (indicators) has proved its practical feasibility. The comparative analysis of its use made it possible to characterize the state and trends in the production systems in the territories of the region, to identify new tasks for finding the potential for economic development, to determine the directions for improving the mechanisms of regional policy.

The project №19-410-240007 «Metrics of factorial assessment of reserves of internal potential and the effects of growth in labour productivity in non-resource sectors of the economy to support the digitization of the integration processes of business entities in the region» was funded by RFBR, Government of Krasnoyarsk Region and Krasnoyarsk Regional Fund of Science.

\section{References}

1. M.V.Simonova, Labor Economics 6 (3), 1179 (2019)

2. Z. S. Rakhmatullin, Bulletin of the Chelyabinsk State University. Economics 33 (31 (246)), 36 (2011)

3. S.E. Polovkin, Value Added Management of Business Entities. Abstract of dissertation for the degree of candidate of economic sciences, Kazan, (2007)

4. A. A. Kuklin, I. V. Korobkov, Regional Economy 14 (4), 1145 (2018)

5. V.A. Vaisburd, M.V. Simonova I.V. Bogatyreva, E.G. Vanina, E. R. Jheleznikova, International J. Economics and Financial Issues 55, 157 (2016)

6. C. Syrerson, J. of Economic Literature 49, 326 (2011). 10.1257 / jel.49.2.326

7. A. V. Belokopytov, A. N. Ternovchuk, Labor Economics 6 (1), 285 (2019)

8. Automated information subsystem for monitoring municipalities ("AIS Region MO"). http: //aismmo.econ-krsk.ru/.

9. G. Yu. Gagarina, N. V. Sedova, L. N. Chainikova, L. S. Arkhipova, Regional Economy and Management: Electronic Scientific Journal 3 (59), 10 (2019)

10. V. Zh. Dubrovsky, E.M. Ivanova, N. V. Chuprakova, Journal of new economy 5 (2019) 